\title{
A CONVENIENT FORM OF APPARATUS FOR THE ESTI- MATION OF CARBONIC ACID.
}

\author{
BY ROBEKT H. FORBES.
}

THE form of apparatus for the estimation of carbonic acid devised by the writer and shown herewith, has been fully tested in our laboratories and found to be accurate, cheap, conpact, easily portable, and applicable both to the estimation of carbonic acid in carbonates and to that of carbon in iron by the

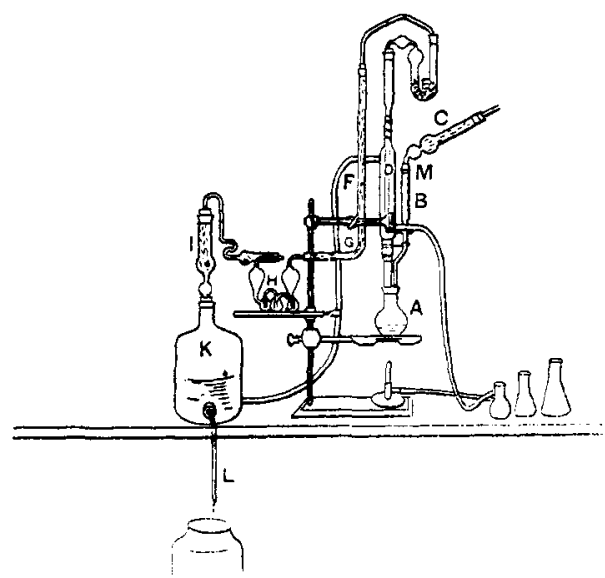

wet combustion with chromic and sulphuric acids. $\mathrm{C}$ is a tube, filled with solid potash, guarding the apparatus from the carbonic acid of the air. The small drop fumnel $\mathrm{B}$ carries acid to the decomposing flask A. The small condenser D returns most of the water vapor, and the hydrochloric acid to the decomposing flask. The small $\mathbf{U}$ tube $\mathbf{E}$, containing a solution of silver sulphate in sulphuric acid, stops hydrogen sulphide and traces of hydrochloric acid. The drying tube F G, of one-half inch combustion tubing, and filled with calcium chloride, finally dries the carbonic acid gas before its absorption at $\mathrm{H}$. The calcium chloride tube I guards the bulbs from moisture, and the aspirating bottle is discharged by the movable tube $\mathrm{L}$.

When used for carbonates, a fifty $c c$. wide mouthed flask is best, but this must be replaced by a $250 \mathrm{cc}$. Erlenmeyer flask when making a wet combustion of carbon.

In practice it is found best, after the evolution flask is in position, to turn down the outlet tube $L$, and regulate the flow en- 
tirely from the stop-cock B. Hydrochloric acid rarely gets beyond the condenser, and the downward pitch of the drying tube $F \mathrm{G}$ hastens the passage of the carbonic acid gas. The whole apparatus occupies less than two square feet of desk room.

UNIVERSITY OF ILLINOIS, AUGUST 25, I 893 .

\section{THE SPECIFIC GRAVITIES OF SOME GEM STONES.'}

BY A. L,YVERSIDGE, M.A., F.R.S., PKOFESSOR OF ChEMISTRY, UNIVERSITY OF SYDXEY.

THE following tables contain the specific gravities of some gem stones which were all in the cut and polished condition except in the cases specified. As the specimens were sufficiently free from flaws and mechanical impurities to be cut and polished for jewelry, the specific gravities can be taken as those of typically pure minerals and the results should be more satisfactory than those obtained from ordinary cabinet specimens, unless it can be shown that the specific gravity is altered by the pressure and other treatment they have received during the process of cutting and polishing.

The specific gravities were taken with special care on an Oertling's best chemical balance by direct weighing, i. e., by suspending the specimen in a very small and light metal stirrup in distilled water. A specific gravity bottle was found, as is well known, to give less accurate results.

The temperature at the time of the determination is given in all cases and the results are corrected to $4^{\circ} \mathrm{C}$. according to Rossetti's determinations of the density of water.

In the last column are given the extremes of specific grarity as given by $F$. W. Clarke in his Constants of Nature.

The numbers refer to those in my catalogue of specimens and added in case of future reference.

1 Read before the Worid's Congress of Chemists. August 23. 1893 . 